\title{
Indicators of passive immunity failure in neonatal calves
}

\author{
Bulent Elitok* \\ Afyon Kocatepe University, Faculty of Veterinary Medicine, Department of Internal Medicine, 03200/Afyonkarahisar-Turkey
}

\begin{abstract}
Newly born calves need colostrum and its immunoglobulins, because they are hypogammaglobulinemic or agammaglobulinemic at birth. In the first days after birth, passive immuno-deficiency occurs after 24-48 hours in the animals when do not take enough colostrum. Serum gamma-glutamyl transferase (GGT) and total protein measurements are also give important information about passive immunity as well as immunoglobulins (especially $\operatorname{IgG}$ ).
\end{abstract}

\section{Introduction}

Passive immunity deficiency; inadequate IgG concentration in the colostrum is directly related to the lack of adequate colostrum removal and $\operatorname{IgG}$ absorptive defects [1-3]. At the end of the first 24 hours following birth, the ability of the intestinal epithelium to absorb macromolecules is lost and passive immune deficiency is formed. $[1,4]$. Serum IgG, GGT) and TP measurements are the most common indicators of passive transfere failure in calves.

\section{Immunglobulin G (IgG)}

Measurement of serum IgG concentrations is considered to be the most common method for determining passive transfer failure in neonatal calves and a serum IgG concentration of $>10 \mathrm{~g} / \mathrm{L}$ is considered to be a criterion for providing sufficient passive immunity [3-6].

The primate immunoglobulin, IgG, of bovine colostrum originates from maternal serum IgG and reaches the maximum level in maternal breasts. Mohendra and Merriman (1977) argued that blood serum IgG levels in colostrum-fed calves increased within a few hours [7]. Some investigators [8-10] reported that IgG levels in colostrum after birth were highest in 3rd milk and then decreased.

\section{Gamma-glutamyl transferase (GGT)}

Many researchers [11,12] who claim that Ig measurements are expensive and time-consuming have investigated some of the alterations of some parameters, such as enzymes that would prove passive immunity. The detection of certain enzymes such as GGT provides important information on passive immunity and colostrum uptake in newborns [11]. As a matter of fact, in the colostrum-receiving animals, the maternal GGT enzyme is taken together with the immunoglobulins at high dose, and the level of this enzyme in the calf blood increases.

Weaver et al. (2000) reported that there is a positive correlation between GGT activity and Ig concentrations, and that GGT may be a good indicator of passive trans- ference in the cold [13]. Perino et al. (1993) reported that there is a parallels between GGT and IgG concentrations, but the correlation between them is weak [14]. Parish et al. (1997), according to the model they set in the same subject; GGT enzyme levels should be $>200$ IU / L on day 1 after colostrum uptake> $100 \mathrm{IU} / \mathrm{L}$ on day $4>75 \mathrm{IU} / \mathrm{L}$ at the end of week 1, passive transfer failure of $<50 \mathrm{IU} / \mathrm{L}$ GGT levels at the end of 2nd week [15] .
However, it is noted that this bulge does not occur only in the ice of the colostrum, which is observed on the ice, and is fed with milk or milk substitutes [16].

\section{Serum Total Protein (TP)}

Some investigators [17] found that the mortality rates of icebergs with low serum TP values of $50 \mathrm{~g} / \mathrm{L}$ in the early stages of life were 3 to 6 times higher than those with $60 \mathrm{mg} / \mathrm{L}$ of high serum TP concentration. Serum TP levels are not very specific, but above $6 \mathrm{~g} / \mathrm{dl}$ is considered a sign of adequate passive immunity $[1,2,13]$. Pekcan et al. (2013) found that there was a positive correlation between passive transfer success and GGT enzyme levels in calves receiving enough colostrum and reported that GGT enzyme and TP concentrations were high in high Ig levels [18]. There are other studies that have shown that GGT enzyme levels rise very rapidly [19] and that these elevated levels are higher than adult cattle, as demonstrated by the presence of colostrum by serum protein and serum protein electrophoresis $[13,14]$. The positive correlation between serum TP and IgG concentrations was determined by McBeath et al. [20] in 185 studies with calves. In a more recent study [21], it was reported that $5.2 \mathrm{~g} / \mathrm{dL}$ of serum TP concentration in normal calves equals $1000 \mathrm{mg} / \mathrm{dL}$ IgG concentration, which is greater than $80 \%$ accuracy. In another study [10] it is reported that passive transeferricity is the case when this ratio corresponds to $5.5 \mathrm{mg} / \mathrm{dL}$ protein equivalence.

As a result; GGT enzyme levels and TP concentrations also provide important information in determining the passive transfer failure as well as measuring the IgG concentrations in newborn calves. Measuring these three parameters at the same time is clear that it will allow us to make more precise decisions about the failure of passive transfer status.

\section{References}

1. Gvozdic D, Stojic V, Fratric N, Pesut O, Jovanovic I, et al. (2007) Eficiency of Immunoglobulin Absorption in Newborn Calves Receiving Oral Clinoptilolite Treatment. Lucrari Stitnlifice Medicina Veterinara XL: 234-242.

${ }^{\star}$ Correspondence to: Bulent Elitok, Afyon Kocatepe University, Faculty of Veterinary Medicine, Department of Internal Medicine, 03200/AfyonkarahisarTurkey, E-mail: elitok1969@hotmail.com

Key words: passive transfer, insufficiency, calves, enzyme, total protein

Received: April 07, 2018; Accepted: April 30, 2018; Published: May 03, 2018 
2. Heinrichs AJ, Elizindi-Salazar AJ (2009) Reducing Failure of Passive Immunoglobulin Transfer in Dairy Calves. Revue Med Vet 160: 436-440.

3. Quigley JD (2004) The Role of Oral Immunoglobulins in Systemic and Intestinal Immunity of Neonatal Calves, Ames, IA, Iowa State University.

4. Jaster HE (2005) Evaluation of quality, quantity, and timing of colostrum feeding on immunoglobulin G1 absorption in Jersey calves. J Dairy Sci 88: 296-302. [Crossref]

5. Abel Francisco SF, Quigley JD (1993) Serum immunoglobulin concentrations after feeding maternal colostrum or maternal colostrum plus colostral supplement to dairy calves. Am J Vet Res 54: 1051-1054. [Crossref]

6. Fecteau GG, Arsenault J, Pare J, Van Metre DC, Holmberg CA et al. (2013) Prediction of serum igg concentration by indirect techniques with adjustment for age and clinica and laboratory covariates in critically ill newborn calves. Can J Vet Res 77: 89-94. [Crossref]

7. Merriman MJ (1971) Serum Immunoglobulins in Newborn Calves Before and After Colostrum Feeding. Can J Comp Med 35: 269-273. [Crossref]

8. Pritchett LC, Gay CC, Besser TE, Hancock DD (1991) Management and production factors influencing immunoglobulin G1 concentration in colostrum from Holstein cows. J Dairy Sci 74: 2336-2341. [Crossref]

9. Muller LD, Ellinger DK (1981) Colostral immunoglobulin concentrations among breeds of dairy cattle. J Dairy Sci 64:1727-1730. [Crossref]

10. Tyler JW, Steevens BJ, Hostetler DE, Holle JM, Denbigh JL Jr (1999) Colostral immunoglobulin concentrations in Holstein and Guernsey cows. Am J Vet Res 60: 1136-1139. [Crossref]

11. Zarilli A, Micera E, Lacarpia N, Lombardi P, Pero ME, et al. (2003) Evaluation of goat colostrum quality by determining enzyme activity levels. Livest Prod Sci 83: 317-320.
12. Lombardi P, Avallone L, Pagnini U, D'angelo D, Bogin E (2001) Evaluation of buffalo colostrum quality by estimationof enzyme activity levels. J Food Prot 64: 1265-1267. [Crossref]

13. Weaver DM, Tyler JW, Vanmetre DC, Hostetler DE, Barrington GM (2000) Passive Transfer of Colostral Immunoglobulins in Calves. J Vet Intern Med 14: 569-577. [Crossref]

14. Perino LJ, Sutherland RL, Woollen NE (1993) Serum gamma-glutamyltransferase activity and protein concentration at birth and after suckling in calves with adequate and inadequate passive transfer of immunoglobulin G. Am J Vet Res 54: 56-59. [Crossref]

15. Parish SM, Tyler JW, Besser TE, Gay CC, KrytenbergD (1997) Prediction of serum IgG1 concentration in Holstein calves using serum gamma glutamyltransferase activity. $J$ Vet Intern Med 11: 344-347. [Crossref]

16. Boediker R (1991) Die Bestimung der GGT im Serum als Indikator für die Kolostralmilchversorgung des Kalbes. Tierärztliche Umschau 46: 190-194.

17. Donovan GA, Dohoo IR, Montgomery DM, Bennett FL (1998) Associations between passive immunity and morbidity and mortality in dairy heifers in Florida, USA. Prevent Vet Med 34: 31-46. [Crossref]

18. Pekcan M, Fidancı UR, Yuceer B, Ozbeyaz C (2013) Estimation of passive immunity in newborn calves with routine clinical chemistry measurements. Ankara Üniv Vet Fak Derg 60: 85-88

19. Thompson JC, Pauli JV (1981) Colostral transfer of gamma glutamyl transpeptidase in calves. $N$ Z Vet $J$ 29: 223-226. [Crossref]

20. Tyler JW, Hancock DD, Parish SM, sanders SG, Wilson LK, et al. (1996) Evaluation of 3 assays for failure of passive transfer in calves. J Vet Intern Med 10: 304-307. [Crossref]

Copyright: (C2018 Elitok B. This is an open-access article distributed under the terms of the Creative Commons Attribution License, which permits unrestricted use, distribution, and reproduction in any medium, provided the original author and source are credited. 